\section{Thiamine and its Mono-, Di-, and Triphosphoric Esters Content of Normal Rat Tissues}

Up to the present, no methods have been described for the separation and determination of Thiamine ${ }^{1}$ and its phosphoric esters in animal tissues (particularly TTP recently detected in liver ${ }^{2}$, and in kidneys and brain ${ }^{3}$ of rats).

\section{Riassunto}

L'uso di un nuovo metodo cromatografico per la separazione della Tiamina e dei suoi esteri mono, di, e trifosforico nei tessuti animali ha permesso di definire, per la prima volta in termini quantitativi, la presenza del trifosfato nei tessuti stessi. L'organo più ricco di questo estere è il fegato, seguito dal cuore, dal rene e dal cervello nell'ordine.

Content of $T, T M P, T D P$, and $T T P$ in some rat tissues (mean \pm s. e.)

\begin{tabular}{|c|c|c|c|c|c|c|c|c|}
\hline \multirow{2}{*}{ Compound } & \multicolumn{2}{|l|}{ Brain (5) } & \multicolumn{2}{|c|}{ Liver (6) } & \multicolumn{2}{|l|}{ Heart (5) } & \multicolumn{2}{|l|}{ Kidney (7) } \\
\hline & $\mu g / g$ & $\%$ & $\mu g / g$ & $\%$ & $\mu g / g$ & $\%$ & $\mathrm{Hg} / \mathrm{g}$ & $\%$ \\
\hline Thiamine & $0.11 \pm 0.08$ & $4 \cdot 4$ & $0.24 \pm 0.01$ & $3 \cdot 5$ & $0.16 \pm 0.02$ & $2 \cdot 3$ & $0.22 \pm 0.02$ & $6 \cdot 2$ \\
\hline Thiamine monophosphate & $0.30 \pm 0.09$ & $11 \cdot 5$ & $0.66 \pm 0.01$ & 9.4 & $0.41 \pm 0.05$ & $5 \cdot 9$ & $0.35 \pm 0.06$ & 9.8 \\
\hline Thiamine diphosphate & $2 \cdot 61 \pm 0.15$ & $78 \cdot 9$ & $6.81 \pm 0.44$ & 77.9 & $7.44 \pm 0.44$ & $86 \cdot 0$ & $3.47 \pm 0.13$ & $78 \cdot 6$ \\
\hline Thiamine triphosphate & $0.19 \pm 0.03$ & $5 \cdot 0$ & $0.92 \pm 0.13$ & $9 \cdot 0$ & $0.57 \pm 0.04$ & $5 \cdot 6$ & $0.27 \pm 0.01$ & $5 \cdot 2$ \\
\hline
\end{tabular}

$\langle$, Number of determinations; $\%: T$, as percentage of total $T$ found in the tissue.

On the basis of a previous research 4 , in which the analytical conditions necessary for the chromatographic separation and the estimation of T, TMP, TDP and TTP in pure solutions were described, we have worked out a quantitative method for their estimation in animal tissues. The principle of this method can be summarized as follows:

The tissue is homogenized in cold $5 \% \mathrm{TCA}$. The extract, free from proteins, is adjusted to $\mathrm{pH} 6 \cdot 7-6.8$ with $40 \% \mathrm{NaOH}$, and passed through a charcoal column, prepared according to SILIPRANDI and SilIPRANDI ${ }^{5}$. After washing with $\mathrm{H}_{2} \mathrm{O}$, an elution with $60-70 \mathrm{ml}$ of $10 \%$ npropanol is carried out. The eluate is concentrated to about $5 \mathrm{ml}$ in a Rinco rotating evaporator at $25-30^{\circ} \mathrm{C}$, under vacuum. The concentrate and washings $(15 \mathrm{ml})$, after addition of $0.8 \mathrm{ml} 0.1 \mathrm{~N} \mathrm{HCl}$, are chromatographied on Dowex $1, \times 8$, acetate form, column, size $8 \times 25 \mathrm{~mm}$, and washed with $10 \mathrm{ml}$ of $\mathrm{H}_{2} \mathrm{O}$. The percolate and washings are collected in a $25 \mathrm{ml}$ volumetric flask and the $\mathrm{T}$ and TMP content is estimated by difference before and after Takadiastase digestion (Thiochrome method ${ }^{6}$ ). The TDP is eluted from the resin column by means of $20 \mathrm{ml}$ of $0.02 M$ sodium acetate solution in $0.04 M$ acetic acid. TTP is eluted last with $20 \mathrm{ml}$ of $M$ acetate buffer at $\mathrm{pH} \cdot \mathbf{4} \cdot \mathbf{5}$. After Takadiastase hydrolysis, the TDP content is determined directly in the eluted solution, and the TTP content after percolation through Amberlite IRC 50, buffered at $\mathrm{pH} 4 \cdot 5^{\text {? }}$.

With this method the recovery of the extracted Tcompounds is about $95 \%$ with good reproducibility. A series of determinations carried out on rat tissues have given the results reported in the Table.

As can be seen, all the tissues examined contain small amounts of TMP and TTP, the biochemical significance of which is still to be elucidated. The organ richest in TTP is the liver, followed by the heart, kidney, and brain. However, by far the most abundant $T$ compound (about $80 \%$ of the total T) is TDP.

G. Rindi and L. De Giuseppe

Istituto di Fisiologia, Università di Pavia (Italy) and Vister Research Laboratories, Casatenovo (Italy), April 21, 1960.
1 The following abbreviations have been used: $\mathrm{T}=$ Thiamine; TMP $=$ Thiamine monophosphate; TDP $=$ Thiamine diphosphate; TTP $=$ Thiamine triphosphate; TCA = Trichloracetic acid.

2 A. Rosst-Fanelit, N. Siliprand, and P. Fasella, Science 116, 711 (1952).

3 H. Greiling and L. Kiesow, Z. Naturforsch. 13b, 251 (1958),

4. DE Giusepre and G. Rindi, J. Chromat. 1, 545 (1958).

5. Siliprandi and N. Siliprandi, Biochim. biophys. Acta 14, $52(1954)$.

- Assoc. Vitamin Chemists, Methods of Vitamin Assay (Inter. Publ., 2nd Ed., 1951), p. 111.

7 E. E. Vannatta and L. E. Harris, J. Amer. pharm. Ass. 48 , $34(1959)$.

\section{Synthesis at High Pressure and Lattice Constants of Normal Cupric Carbonate}

Normal cupric carbonate, $\mathrm{CuCO}_{3}$, has not previously been prepared, although a number of basic carbonates exist, of which malachite, $\mathrm{CuCO}_{3} \cdot \mathrm{Cu}(\mathrm{OH})_{2}$, and azurite, $\mathrm{Cu}(\mathrm{OH})_{2} \cdot 2 \mathrm{CuCO}_{3}$, are the best known.

Attempts were made to prepare $\mathrm{CuCO}_{3}$ by subjecting dry cupric oxide to $\mathrm{CO}_{2}$-pressures of up to 5000 bars and temperatures ranging from $100^{\circ} \mathrm{C}$ to $600^{\circ} \mathrm{C}$ in a hydrostatic bomb which is described elsewhere ${ }^{1}$. No reaction took place.

Subsequently a finely ground equimolar mixture of anhydrous sodium carbonate and cupric sulphate was subjected to a pressure of 20000 bars and a temperature of $550^{\circ} \mathrm{C}$ in the 'simple squeezer' high-pressure apparatus developed by GRIGGs and KENNEDY ${ }^{2}$. After $1 \mathrm{~h}$ under these conditions the sample was quenched at pressure. An X-ray powder diffraction examination of the products showed, in addition to the known patterns of $\mathrm{CuSO}_{4}$, $\mathrm{Na}_{2} \mathrm{CO}_{3}$ and $\mathrm{Na}_{2} \mathrm{SO}_{4}$, a small number of weak lines which could be ascribed to a rhombohedral lattice with nearly the same dimensions as siderite ${ }^{3}$. The same but weaker

1 H. Heard, to be published.

2 D.T. Gricos and G. C. KennedY, Amer. J. Sel. 254, 722 (1956).

3 W. E. Sharp, Amer. Mineralogist, 45, 24 (1960). 